\title{
Atypical Glandular Cell
}

National Cancer Institute

\section{Source}

National Cancer Institute. Atypical Glandular Cell. NCI Thesaurus. Code C36912.

An abnormal endocervical or endometrial cell found in a cervical smear, not further

characterized as neoplastic or non-neoplastic. It is often associated with clinically significant uterine lesions. 